\title{
S-Phase Kinase-Associated Protein 2
}

National Cancer Institute

\section{Source}

National Cancer Institute. S-Phase Kinase-Associated Protein 2. NCI Thesaurus. Code C29972.

S-phase kinase-associated protein 2 ( $424 \mathrm{aa}, \sim 48 \mathrm{kDa}$ ) is encoded by the human SKP2 gene. This protein is involved in the regulation of protein-protein interactions that govern the cell cycle. 